\title{
Post Graduation Assessment Of Learning Outcomes
}

Glenn Maples, University of Louisiana at Lafayette Anna M. Greco, University of Louisiana at Lafayette John R. Tanner, University of Louisiana-Lafayette

\begin{abstract}
The objective of this work is to suggest a process for improving the assessment of educational outcomes in universities. Improved accountability and assessment has become an important direction in academic institutional research, but the underlying question -how best to accomplish this goal is an open question. A framework is first described which promotes the categorization of academic assessment. Based on this framework, a preliminary instrument was developed and piloted. The results of this study are reported and plans for future efforts are described.
\end{abstract}

Keywords: alumni survey, academic assessment, business graduates, undergraduate experiences

\section{INTRODUCTION}

$\mathscr{Q}$ niversity educators find themselves under increasing pressure to be more accountable for the end results of education and research. The federal government provides much of this force, for while stopping short of requiring a university version of "No Child Left Behind," government's increasing role in provident the financial means to support education has led it to assume a greater role in directing university processes and outcomes. For instance, in 2000, President Clinton signed executive order 13185, calling for increased accountability in university research (Federal Register 2000). And in 2006 the Spellings Report (Charting the Future of U.S. Higher Education) called for the creation of a system to track individual students' academic, enrollment, and financial-aid information (Fischer 2006).

Nor is the federal government the only agency pressing or greater accountability. A simple web search finds almost every state government exploring methods to increase the accountability in higher education. Similarly, accreditation bodies such as the AACSB have focused on outcomes assessment as a primary method to increase the accountability in the educational process (for instance, Martell and Calderon 2005).

Both intangibility and multidimensionality (Donabedian, 1980; Ehlers, 2004) greatly increase the difficulty in measuring the outcomes of education. This is especially true of teaching - the almost infinite number and perspectives of stakeholders in the educational process each provide potential metrics-however the difficulty in agreeing on a system of metrics that universally measures the success of university teaching underscores this point. In general however, education seems to be looking outward to measure its results.

\section{A FRAMEWORK FOR CLASSIFYING EDUCATIONAL SUCCESS METRICS}

This research categorizes measures of student outcomes as either in process or out of process. In process refers to measurements taken while the student attends school while out of process refers to measurements taken after the student has left school -either as a graduate as a transfer to another institution or ending their education without matriculation. Measures may also be contrasted between performance (sometimes based on outcome demographics such as retention or graduation rates) and attitudes the micro level (based on attitudinal assessments of outcomes). Applying this typology across disparate stakeholder groups provides a useful framework for classifying outcome measures. 
Typical measures in each quadrant of the framework include:

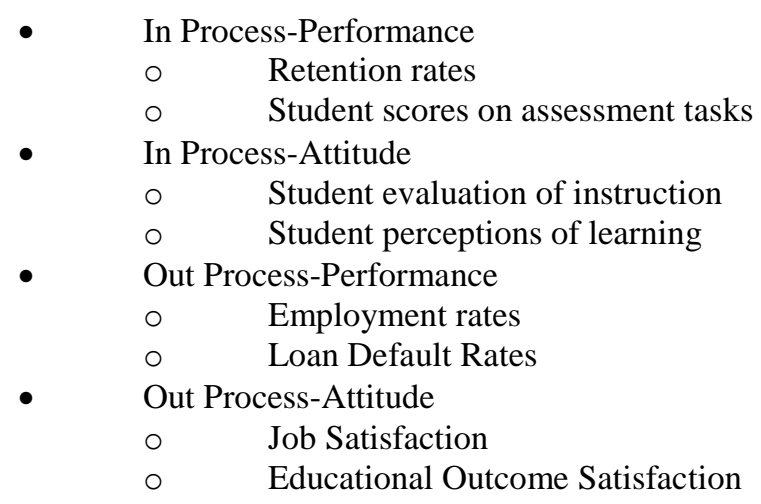

This framework demonstrates that a multitude of potential measures exist for the assessment of educational success, however the disparate audiences interpreting these assessments do so from different perspectives. For example, academic institutions might well assign a different significance to an Out Process-Performance Measure like Employment Rate than that assigned by the student (or his family) who has not found work.

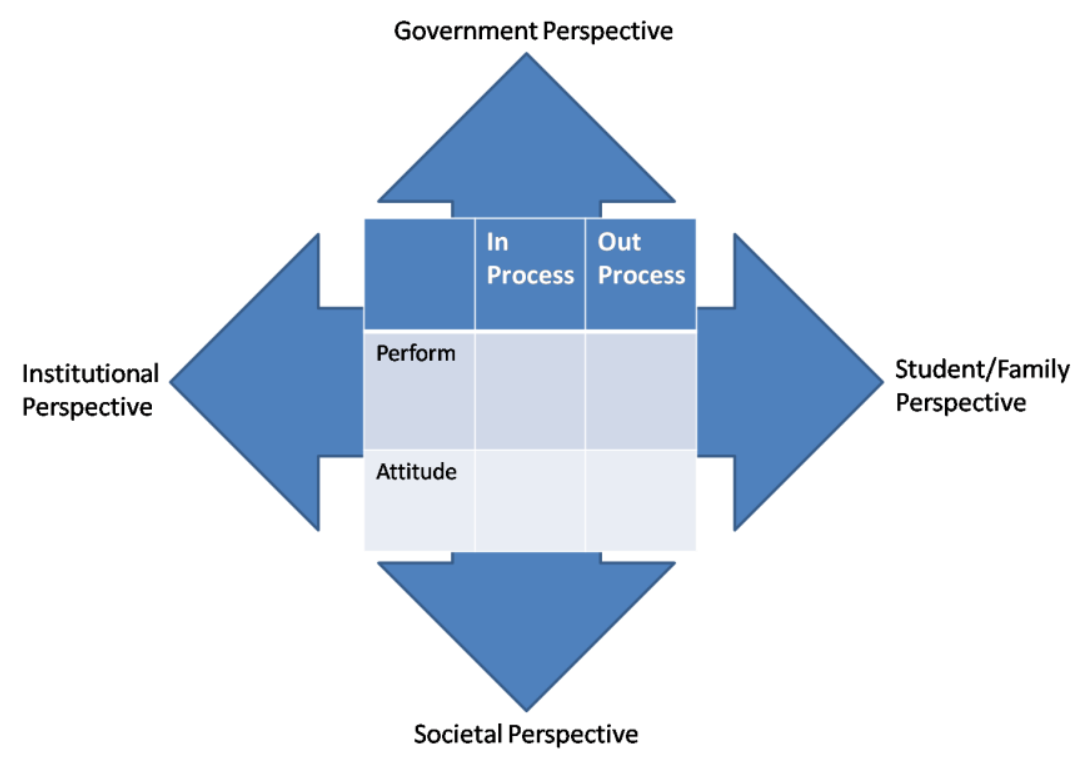

Figure 1- Educational Assessment Framework

This framework also demonstrates a primary cause of the perceived disconnect between academic assessment of education and that of others-academic institutions rarely concern themselves with Out Process measures of educational success while the government and society at large has much access to In Process measures. Moreover, traditional institutional measures of educational success such as students' grades on exams tend to be relatively poor indicators of the overall quality of educational outcome (Williams and Clark 2004).

In summary, this framework provides a reasoned basis for suggesting which methods are most likely to improve educational outcome assessment: 
1. Increase the amount of influence by external agencies (including those representing government as well as society and its organizations) on In Process assessment activities; or,

2. Increase the amount of Out Process assessment done by educational institutions.

Increasing the amount of influence that external agencies have on In Process assessment has the potential to greatly both increase the relevance and improve the interpretations of In Process assessment. It has been well documented that both students and faculty have significant problems in providing causal explanations for student performance. Students tend to attribute academic success and failure to personal effort. In one respect this may increase the probability of future success - if a student has failed but sees this failure as the result of lack of effort, the ability of that student to change effort gives hope for future success (Williams and Clark $2002 \&$ Yan and Gaier 1994). However, students are more likely to attribute success to their efforts than failure to a lack of effort (El-Hindi and Childers 1996). Likewise, research has shown that faculty tend to take credit for academic success but will duck responsibility for student failures (McAllister 1996) Introduction of external judges of educational outcomes could lead to less biased attribution of the causes of success and failure in the classroom.

However, this suggestion is also fraught with difficulties. Such a move would be at odds with the wellestablished principle of academic freedom and might well be the proverbial "camel's nose," allowing society at large the ability to shape and even control what is taught and how it is taught in universities. Moreover, it would be prohibitively expensive to bring in outside expertise to each class, the external expertise is likely to be divisive (especially between competing external agendas), and such a process is likely to be extremely disruptive to the educational process.

For these reasons, we believe that the second alternative, increasing the Out Process assessment of students provides the most likely method to measure and improve educational outcomes. The rest of this paper describes the efforts to pilot an instrument that focuses on collecting student Out Process data, the results of this effort, and plans future research.

\section{DEVELOPMENT OF THE INSTRUMENT}

Although there has been some research into using alumni research to improve accountability (for instance, Borden 2005) little recent research has focused directly on the idea of using alumni surveys as a means to assess student learning and thereby increase educational accountability. In 2005 Edgar and Hyde administered a survey to health communication professionals; however, the focus was on program direction rather than assessment. McGuire and Case (1999) report on a very large sample of alumni ( $>>6,000)$ conducted in 1995 which allowed significant inter-institutional comparisons but we were unable to find more recent work replicating the study.

However, many if not most schools conduct periodic surveys of their alumni. Cabrera, Weerts, and Zulick (2005) provide three primary objectives in alumni surveys: the preparation of alumni for employment, an evaluation of student experiences, and degree of support for their institution. Belcheir (2002) reported on a large sample drawn from alumni at Boise State University over a period of 10 years. During this period, former students showed increasing desire for skills that lead to employability, internships and skills related to problems solving and dealing with data. Porter and Umbach (2006) advanced the notion that individual departments may have profound effects on student satisfaction with education as well as their perceptions of employable skill development.

With this research as a base, an instrument was constructed focusing on the following areas for the college of business: skills learned, willingness to participate in the college and university centered activities, experiences while enrolled in the college of business, and employment. The instrument was then mailed to 600 graduates from the College of Business Administration at a regional southern university. Usable responses were received from 50 graduates, for a response rate of 8.33 percent. This is within the acceptable response rate according to a widelycited source on survey research (Alreck and Settle, 2004).

The idea of student as customers is certainly a contentious one-advanced in the 1980's as a result of Total Quality Management many academics bristle at the concept (for instance, Albanese 1999). Chief among the 
arguments against considering students as customers is the thought that students do not have the experience or knowledge to be effective judges of their educational requirements. However, this premise is stood on its head when considering graduates-after all they have the best knowledge of their own educational needs and shortcomings. Thus the skill section of the survey with was designed in accordance with the service quality literature (Zeithaml, Parasuraman and Berry 1990) which allowed gap scores to be calculated. The mechanics of the survey followed those of the SERVPERF (Cronin and Taylor 1992) with two five-point Likert scales employed, one to measure student perceptions of importance of various skills and the other capturing perceptions of performance.

This research adopts the following definition of community — "Community ... refers to social relationships that individuals have based on group consensus, shared norms and values, common goals, and feelings of identification, belonging and trust." (Small \& Supple, 2001, p. 3) In seeking to ascertain student willingness to participate as part of the university community, four factors considered to underlie motivation for this community involvement were investigated: self-improvement (what can involvement do for me), institutional obligation (what I owe to my institution), the ability to help others (what can I do for others) and moral imperative (because it is the right thing to do).

The instrument collected information about college experiences using five-point Likert scale responses. Questions asked graduates for perceptions of faculty interest in student welfare, opportunities for faculty -student interaction, quality of teaching and advising, ability to relate academics to the real world, and whether there was at least one faculty member in their major who made a real difference to the student.

Finally, employment and demographic questions include employment status, how long after graduation before they were employed, job satisfaction, their salary range, whether they were employed in field, sex and grade point average.

\section{SURVEY RESULTS}

Participants usually rated items toward the upper end of the scales for salary, GPA, job satisfaction and whether at least one member of their faculty made a real difference to the student. These scales were recoded - with the highest scale or band coded as a 2 and the other rating points or band coded as $1 \mathrm{~s}$. Thus, in the following discussion, graduates classified as high income were in the highest group (over \$50,000), high GPAs include those whose GPAs were 3.6 or higher, high satisfaction indicates a 4 on a 1 to 4 scale and High Inspiration includes those students scoring a 5 for this item on a 5 point scale.

\section{DISCUSSION, LIMITATIONS AND FURTHER RESEARCH}

In all, five relationships were significant at the .05 level. Two of these significant relationships were related to the graduate working in field (see Tables 1 and 2). Graduates working in field were significantly more likely to have a higher GPA and to have been inspired by a faculty member and to have greater job satisfaction. However, as shown in Tables 3 and 4, graduates working in field were not significantly different from those not working in field with respect to salary level or job satisfaction. The number of significant relationships linked to working in field is not surprising. After all, graduating with a degree represents the culmination of 4 or more years of study and investment. It is almost inescapable that those students not working in field are less likely to be positive about their experience. 
Table 1

Comparison of Respondents Working in Their Major Fields vs. Not Working in Field by Grade-Point Average (GPA) Groupings

\begin{tabular}{|c|c|c|c|c|}
\hline & \multicolumn{2}{|c|}{ GPA Groupings } & \multirow{2}{*}{$\boldsymbol{\chi}^{\mathbf{2}}$} & \multirow{2}{*}{ p-value* } \\
\cline { 2 - 3 } Working in Major Field? & Less than 3.60 & $\mathbf{3 . 6 0}$ or Higher & \multirow{2}{*}{3.972} & $.046^{*}$ \\
\hline Yes & 20 & 18 & 3.972 \\
\hline No & 8 & 1 &
\end{tabular}

* Significant at $\alpha=.05$

Table 2

Comparison of Respondents Working in Their Major Fields vs. Not Working in Major Field by Faculty Inspiration Levels

\begin{tabular}{|c|c|c|c|c|}
\hline \multirow[b]{2}{*}{ Working in Major Field? } & \multicolumn{2}{|c|}{$\begin{array}{c}\text { Faculty Inspiration Levels } \\
\end{array}$} & \multirow[b]{2}{*}{$\chi^{2}$} & \multirow[b]{2}{*}{ p-value* } \\
\hline & $\begin{array}{c}\text { High Level of Faculty } \\
\text { Inspiration }\end{array}$ & $\begin{array}{c}\text { Low Level of Faculty } \\
\text { Inspiration }\end{array}$ & & \\
\hline Yes & 28 & 10 & \multirow[b]{2}{*}{5.277} & \multirow[b]{2}{*}{$.022 *$} \\
\hline No & 3 & 6 & & \\
\hline
\end{tabular}

* Significant at $\alpha=.05$

Table 3

Comparison of Respondents Working in Their Major Fields vs. Not Working in Major Field by Salary Groupings

\begin{tabular}{|c|c|c|c|c|}
\hline \multirow{2}{*}{ Working in Major Field? } & \multicolumn{2}{|c|}{ Annual Salary Levels } & \multirow{2}{*}{$\chi^{2}$} & \multirow{2}{*}{ p-value* } \\
\cline { 2 - 3 } & $\mathbf{\$ 5 0 , 0 0 0}$ or Less & More than $\mathbf{\$ 5 0 , 0 0 0}$ & \multirow{2}{*}{3.453} & .067 \\
\hline Yes & 16 & 21 & 2 & \\
\hline
\end{tabular}

* Significant at $\alpha=.10$

Table 4

Comparison of Respondents Working in Their Major Fields vs. Not Working in Major Field by Job Satisfaction Levels

\begin{tabular}{|c|c|c|c|c|}
\hline \multirow[b]{2}{*}{ Working in Major Field? } & \multicolumn{2}{|c|}{$\begin{array}{c}\text { Job Satisfaction Levels } \\
\end{array}$} & \multirow[b]{2}{*}{$\chi^{2}$} & \multirow[b]{2}{*}{ p-value* } \\
\hline & $\begin{array}{c}\text { High Level of Job } \\
\text { Satisfaction }\end{array}$ & $\begin{array}{c}\text { Low Level of Job } \\
\text { Satisfaction } \\
\end{array}$ & & \\
\hline Yes & 24 & 11 & & \\
\hline No & 3 & 6 & 3.750 & .053 \\
\hline
\end{tabular}

* Significant at $\alpha=.10$

In addition to the significant relationship found in Table 2 between inspiration and working in field, three other significant relationships were related to inspiration (see Tables 5, 6, and 7). Graduates who strongly agreed that a faculty member had made a real difference in their education had significantly higher salaries, were more likely to strongly agree that there were many opportunities for faculty/student interaction, were more likely to work in field, and tended to have to have earned higher GPAs than those students not in the high inspiration group. Although no model is advanced in this research to suggest causation, the many positive outcomes associated with teacher inspiration indicates that it seems likely that even at the university level a teacher can make a real difference in students lives. 
Table 5

Comparison of Faculty Inspiration Levels with Salary Groupings

\begin{tabular}{|c|c|c|c|c|}
\hline \multirow{2}{*}{$\begin{array}{c}\text { Level of Inspiration by } \\
\text { Faculty }\end{array}$} & \multicolumn{2}{|c|}{$\begin{array}{c}\text { Annual Salary Levels } \\
\end{array}$} & \multirow[b]{2}{*}{$\chi^{2}$} & \multirow[b]{2}{*}{ p-value* } \\
\hline & $\$ 50,000$ or Less & More than $\$ 50,000$ & & \\
\hline High Inspiration & 12 & 20 & \multirow[b]{2}{*}{6.747} & \multirow[b]{2}{*}{$.009 *$} \\
\hline Lower Inspiration & 13 & 4 & & \\
\hline
\end{tabular}

* Significant at $\alpha=.05$

Table 6

Comparison of Faculty Inspiration Levels with Faculty Interaction

\begin{tabular}{|c|c|c|c|c|}
\hline \multirow{2}{*}{$\begin{array}{c}\text { Level of Inspiration by } \\
\text { Faculty }\end{array}$} & \multicolumn{2}{|c|}{ Opportunities for Student/Faculty Interaction } & \multirow[b]{2}{*}{$\chi^{2}$} & \multirow[b]{2}{*}{ p-value* } \\
\hline & Many Opportunities & Fewer Opportunities & & \\
\hline High Inspiration & 8 & 25 & & \\
\hline Lower Inspiration & 0 & 15 & 4.364 & $.037 *$ \\
\hline
\end{tabular}

* Significant at $\alpha=.05$

Table 7

Comparison of Faculty Inspiration Levels with Grade-Point Average (GPA) Groupings

\begin{tabular}{|c|c|c|c|c|}
\hline \multirow{2}{*}{$\begin{array}{c}\text { Level of Inspiration by } \\
\text { Faculty }\end{array}$} & \multicolumn{2}{|c|}{ GPA Groupings } & \multirow[b]{2}{*}{$\chi^{2}$} & \multirow[b]{2}{*}{ p-value* } \\
\hline & Less than 3.60 & 3.60 or Higher & & \\
\hline High Inspiration & 14 & 19 & \multirow[b]{2}{*}{9.666} & \multirow[b]{2}{*}{$.002 *$} \\
\hline Lower Inspiration & 15 & 2 & & \\
\hline
\end{tabular}

* Significant at $\alpha=.05$

One remarkable point of the study was the high number of significant results, either at the .05 or .10 level, despite the relatively low number of respondents. Combined with the relatively low power of the non-parametric test used, this tends to point to a very strong relationship between the variables.

The two highest gap scores (importance of the skill - institutional performance in teaching the skill) were seen in items relating to preparing students for careers, followed by leadership training and managing one's own business. These gap scores correspond with other data from students and other research and provide an immediate opportunity to close the assessment loop.

The chief limitation for this research was the low response rate. Although the problems associated with getting good response rates has been the subject of prior research, the small sample size prevented determination of factor loadings for items. One primary outcome of this research will increased emphasis on finding the means to increase both sample size and response rate.

To be effective in measuring student outcome, researchers and administrators need to focus more attention on measuring the outcomes of students who do not graduate. Future research needs to include a representative sample of these students in the survey sample.

Moreover, the results of this pilot study need to be confirmed in a larger sample. A larger sample size in conjunction with an increased response rate will allow factor analysis on the community attributes which maybe another important indicator of educational outcome. In order to make practical use of this research it will have to be reproduced on a regular basis to allow trends to be identified and to see that action taken to increase educational outcomes are having their desired effects. 


\section{REFERENCES}

1. Albanese, M. 1999 Students Are Not Customers: A Better Model for Medical Education. Academic Medicine, v74 n11 p1172-86 Nov.

2. Alreck, P., and Settle, R. 2004 The Survey Research Handbook, 3rd Edition, p.36. Homewood, IL: Irwin. http://www.archives.gov/federal-register/executive-orders/2000.html

3. Belcheir, M. 2002 Have Graduates' Perceptions Changed Over Time? Research Report 2002-01. Boise State University Internal Report.

4. Borden, V. (2005). Using Alumni Research to Align Program Improvement with Institutional Accountability. New Directions for Institutional Research, v2005 (126) 61-72.

5. Cabrera, A.; Weerts, D.; Zulick, B., 2005 Making an Impact with Alumni Surveys. New Directions for Institutional Research, 2005 (126) 5-17.

6. Cronin Jr., J. and Taylor, S. 1992 Measuring Service Quality: A Reexamination and Extension, Journal of Marketing, 56 (3) 55-68.

7. Donabedian, A. 1980 Explorations in Quality Assessment and Monitoring, Ann Arbor: Sage.

8. Edgar, T. and Hyde, J. 2005 An Alumni-based Evaluation of Graduate Training in Health Communication: Results of a Survey on Careers, Salaries, Competencies, and Emerging Trends Journal of Health Communication, 10(1) 5-25.

9. Ehlers, U.-D. (2007). Quality Literacy - Competencies for Quality Development in Education and eLearning. Educational Technology \& Society, 10 (2), 96-108.

10. El-Hindi, A. and Childers, K. Exploring metacognitive awareness and perceived attributions for academic success and failure: a study of at-risk college students. Presentation at Southwest Educational Research Association, New Orleans LA 1996.

11. Fischer, K. (2006.), The Spellings Report, The Chronicle of Higher Education 53(02) 1.

12. Martell K. and Calderon, T., Assessment of Learning in Business Schools. 2005 Tallahassee, FL: Association for Institutional Research.

13. McAllister, H. 1996 Self-serving bias in the classroom: Who shows it? Who knows it? Journal of Educational Psychology 88, 123-131.

14. McGuire, M. and Casey, J. 1999 Using Comparative Alumni Data for Policy Analysis and Institutional Assessment. New Directions for Institutional Research (101), 81-100.

15. Small, S. \& Supple, A. 2001 Communities as systems: Is a community more than the sum of its parts? In A. Booth \& A.C. Crouter (Eds.), Does it take a village? 161-173. Mahwah, NJ: Lawrence Erlbaum.

16. Umbach, P, and Porter, S. 2002 Research in Higher Education, 43 (2) 209-34.

17. Williams, R. and Clark, L. 2004 College students' ratings of student effort, student ability and teacher input as correlates of student performance on multiple-choice exams. Educational Research, Volume 46, Issue 3 December 2004, $229-239$.

18. Yan, W. and Gaier, E. 1994 Causal attributions for college success and failure: An Asian-American comparison. Journal of Cross-Cultural Psychology 25(1) 146-158.

19. Zeithaml, V., Parasuraman A., and Berry,L. 1990 Delivering Quality Service; Balancing Customer Perceptions and Expectations, Free Press. 
NOTES 